\title{
American Studies in Russia
}

\section{(2) OpenEdition}

\section{Journals}

Édition électronique

URL : https://journals.openedition.org/ejas/366

DOI : $10.4000 /$ ejas.366

ISSN : 1991-9336

Éditeur

European Association for American Studies

Référence électronique

Olga Antsyferova, «American Studies in Russia », European journal of American studies [En ligne], 1-1 । 2006, document 17, mis en ligne le 12 janvier 2006, consulté le 09 juillet 2021. URL : http:// journals.openedition.org/ejas/366 ; DOI : https://doi.org/10.4000/ejas.366

Ce document a été généré automatiquement le 9 juillet 2021.

Creative Commons License 


\section{American Studies in Russia}

1 Interest in the USA, both general and specifically academic, has always existed in Russia, with its own ups and downs. But American studies as an academic discipline started gaining its popularity probably after WWII when there sporadically started to emerge the ever-increasing number of academic books, articles and dissertations in literary and historical research on the USA, the main centers of which were founded at the Academic Research Institute of the USA and Canada, headed by academician G. Arbatov, at the Academic Institute of General History (with academician Bolkhovitinov at the head), at the Gorky Institute of World Literature of the Russian Academy of Sciences (Moscow). American studies have always been taught in the framework of university English Language Departments Syllabi, interest in this discipline gaining fresh impetus during the last decade. Nowadays American Studies go hand in hand or even successfully competes with British studies in all major Russian universities.

2 The year 1974 should be mentioned as a special landmark in Russian American Studies history. That year the first conference of Soviet literary scholars was held at Moscow State University, organized by the Dean of the School of Journalism, Professor Yassen Zasursky. Since then and up to now, on a permanent basis, these annual conferences have been gathering numerous scholars in American Literature from the Soviet and post-Soviet space, putting them in contact with their colleagues from American universities. These annual events give ample opportunity for both leading scholars and newcomers to exchange their views on American literature and culture. The proceedings of these academic events, published annually from 1974 to 2003, give a fairly accurate and complete picture of what is going on in Russian studies of American literature and culture. The ever-changing themes of the Moscow conferences have varied in the wide range determined by the sociopolitical situation in the country: from "October and the Literature of the USA. The Impact of the Great October Socialist Revolution on American Literature and Journalism" (1987) to "Mass Culture: an American Experience" (2002) and "Freedom of Choice in the American Civilization" (2004). After the breakdown of the USSR, the annual conference of the Russian Society of American Culture Studies remains the central and the most regular event of American Studies activities in Russia. It also continues to attract scholars from exSoviet republics and gains manifest interdisciplinary character. The Russian Society for 
American Culture studies remains one of the most influential branches of the Russian Association for American Studies.

3 The Association for the study of the United States was founded in February 1996 at a conference held at Moscow State University. The initiative group of the Moscow University Americanists had been joined by scholars from other universities and research centers of the Russian Federation. Membership of the association soon reached a number of 120 scholars specializing in the fields of history, international relations, literature, social and political sciences, economics and law. Members of the new association represented not only a wide number of regions of Russia, from Saint Petersburg in the West to Khabarovsk in the Far East, but also scholars from Ukraine, Belarus, and Georgia.

4 Regular conferences became a main form of activity of the Association. Eight major conferences have been held since 1995 : "American society on the eve of the XXIst century" (1995), "The New Deal of Franklin D. Roosevelt and its meaning for the USA and Russia" (1995), "The United States and the outer World" (1996), "American studies in Russia: in search of new approaches" (1997), "The USA: origin and development of the national tradition and national character" (1999), "The Problem of "We- the Others" in the context of the historical and cultural experience of the USA"(2001), "Conflict and consensus in American society : theory and practice" (2003), "The conservative tradition in American society : its origin, evolution and contemporary role" (2005).

5 All sessions were followed by publications of the materials of the conferences which consisted of full text articles based on major papers by the participants.

The group of scholars studying American literature at the Department of Contemporary Literatures of Europe and America at the Gorky Institute of World Literature of the Russian Academy of Sciences (Moscow) consists of three senior research fellows, among them doctors of philology Maya M. Koreneva and Ekaterina A. Stetsenko. All of them work on the fundamental joint project -the History of US Literature in six volumes. Volumes I, II, III and IV have already been published and volumes V and VI are in the process of being edited. The scholars also work on they own projects in the fields of the American contemporary novel, mass literature, romanticism, drama...

7 Another major center of American Studies is St. Petersburg. American Studies have been developing there since the middle of the last century. At first it was mainly in literary studies: Yury Kovalev and Alexandra Savurienok, two professors in the Literary History Department of St. Petersburg (then Leningrad) State University, not only belonged to those Soviet scholars who made the literature of the USA the subject of their special interest, but also created the whole school of "americanists" in the local literary scholarship. Nowadays this Department (Chair - Professor Elena Apenko) remains one of the pivotal academic institutions for American Studies in Russia.

Deep changes in our inner and international situations at the turn of the century gave new life and diversity to American studies in the city. Centers for American Studies operate now in the largest two universities of the city, at St. Petersburg State University and at Hertzen Pedagogical State University. Summer Schools, seminars with visiting professors, student exchange programs help to involve many people in American Studies. 
Many projects have Russian-American relations as their specific scope. For example, the annual Russian-American Seminar under the constant supervision of the head of the Department of North American Studies, Professor A.Shirjaev, was launched in 1992 at the Faculty of International Relations of St. Petersburg State University. Scholars in all spheres of the humanities from Russia and the USA meet to discuss both "burning" questions of Russian-American relations and fundamental matters of American Studies in Russia. Due to the constant efforts of professor Y.Tretjakov, the St. Petersburg Branch of the Academy of Sciences hosts the biannual conference "Russian-American Links", where a diversity of mutual influences and controversies in different spheres is discussed. It is very important that gradually American Studies in St. Petersburg become an interdisciplinary project.

One of the signs of the deeply changed situation in Russian-American sociocultural and academic relations, with its increased freedom and flexibility, is what became the Fulbright Summer Schools in the Humanities. They have been held annually since 1997 -the joint initiative of Moscow University and the American Studies Association of Russia, supported and co-organized by the Fulbright Program in Russia. They were founded by Professor MGU Tatiana Venediktova who is not only the Director of the Summer school, but the real heart and soul of the project.

11 Each June the Summer School brings together a group of 25-30 graduate students and university teachers (age varying between 25 and 35) from all over Russia for a session of intense learning and discussion devoted to a subject of common scholarly interest in the humanities. Geographical coverage has been widening over the years, including most regions of Russia ${ }^{1}$, occasionally also Ukraine and Belarus.

The themes of the Summer Schools vary from year to year but continuous emphasis is maintained on American Cultural Studies as a comparative discipline, open dialogically onto the global multicultural space and engaged in active dialogue with Russian academic culture.

13 The themes of the past schools were: "Text as Culture, Culture as Text" (1997), "America as Vision and Spectacle" (1998), "The Imagined Past of America: History as a Cultural Construct" (1999), "Nation as Narration: American and Russian Experience" (2001), "Popular Literature: Cultural Mythmaking and Intercultural Communication", "Everyday Life as Text in American and in Russian", "Values, Canons, Prices: Text as Intercultural Currency". Among teachers in the former Summer schools there were distinguished scholars-American (Sacvan Bercovitch, Paul Lauter, Stephen Mailloux, James Chandler, Marc Seltzer, Karal Ann Marling, John Raeburn, N. Katherine Hayes...) and European (Winfried Fluck, Frederick Brogge, Marc Chénetier...).

One of the most essential tendencies in the development of American Studies in the vast Russian space is the decentering of American Studies activities geographically across Russia which has become an important symptom of the new academic situation after the "perestroika". Several influential Centers of American Studies appeared in Russian cities, more or less remote from a cultural metropolis. Among them Tomsk, Volgograd, Izhevsk can be mentioned.

Teaching and researching the history and foreign policy of the United States began at Tomsk State University at the beginning of the 1950s. In spite of the fact that Tomsk was a "closed" city up to 1990, more than fifty dissertations on American Studies were defended by Siberian scholars. Problems of American foreign policy after W.W. II were 
and are in the focus of interest of professors and postgraduate students of TSU. Between 1995 and 2005, eight issues of the non-periodical American Studies in Siberia were published in Tomsk. In 2003, Prof. Mikhail Pelipas published the book Forged by one chain: The US and Great Britain in the Middle East in 1945-1956. Up to now Tomsk State University is the only center of American Studies in the vast region of Russia that stretches beween Niznii Novgorod and Irkutsk. In 1996, Tomsk State University Professor Mikhail Pelipas-an alumnus of the John F. Kennedy Institute for American Studies Grant Program $(1992,1996)$, founded the Siberian Association for American Studies. For the period of its existence (1996-2003) the Association held several conferences on the problems of comparative studies of American and Siberian histories and gave some help in teaching American history in Universities of West Siberia.

The center for American Studies "Americana" was created in 1995 within Volgograd State University, in Volgograd. The goal of the center is complex, mixing the study of diplomatic, economic, political and cultural connections between Russia and the countries of the American Continent in modern history. The director of the Center is Alexander I. Kubyshkin, Professor of History, Head of Department of Area Studies and International Relations at Volgograd State University. The Center publishes an annual bilingual (Russian and English) series of collections of papers : Americana. (7 vols. between 1997 and 2005). Re-presentation of Canada: Cross-Cultural Reflections on the Canadian Society is an annually published bilingual (Russian and English) series of collections of papers on Canadian Studies by Russian and American scholars. There were also numerous conferences and seminars on American Studies held by the Center between 1998 and 2005, among them "Russia and the Countries of the American Continent: The Experience of Historical Relationship" (September 1997); "University and Civil Society : the practice of Russian-American Cooperation (September 2001); "American Studies" in Russian Scientific, Educational and Cultural Area (October 2003); "The « Old» and the «New» Borders of Eurasia and Northern America: Security and Cooperation Issues (April 2004).

The center for American Studies (CAS) at Udmurt State University (Izhevsk, the Udmurt Republic, Russia) was officially established on April 28, 1998. The Center was the result of intensive and hard work by the University staff that is aimed at developing and strengthening mutually beneficial Russian-American relations. Professor Irina Morozova, the principal initiator, and her colleagues at the Chair for Foreign Literature have been the core ideologists of the Center for many years.

The CAS maintains research, follows educational trends and is actively involved in the creation of the informational database on American Studies. The Center represents a valuable resource as the advising office for a number of international educational programs such as IREX, Fulbright, etc. The Center's library, a donation from the US official agencies and partner organizations, is a nice collection of volumes that include masterpieces of American literature, works on political science, economics, etc. along with reference books on educational opportunities in the USA and periodic editions covering American Studies issues.

19 The CAS staff exercises the local community-oriented approach to developing RussianAmerican projects and very often acts as the principal organizer and coordinator for the professional and student exchanges between the USA and Russia to benefit the communities. 
Ivanovo UP publications is Olga Antsyferova's book The Literary Dimensions of Henry James), but the focus of American studies in Ivanovo has shifted to implementing new long-distance teaching technologies, namely, joint Internet projects coordinated from the Russian side by Professor Olga Antsyferova, Chair of the Comparative Literature Department, and alumna of the John F. Kennedy Institute Grant Program (1999), of the Fulbright Program (2000) and the Salzburg Seminar (2003). The Internet project "The Eurasian Cyberparallel: American Culture via Internet" (http://www.ivanovo.ac.ru/ cyberpar) united the creative efforts of professors and students at eight universities all over Russia and Ukraine. Now large-scale, the "Ivanovo-Wisconsin Exchange Project" (http://wwwivanovo.ac.ru/iv-wis) consists in putting students in the Modern World History course at the University of Wisconsin (Stout) in direct virtual contact with a peer group at Ivanovo State. American and Russian films have been chosen as a common focal point for discussion.

Obviously lacking comprehensiveness, this survey gives several representative examples of various forms of American studies activities in the Russian Federation.

Summing it up, the scene of American studies in Russia is in a state of flux, seeking for reasonable balance between traditional academic borderlines of research and fresh interdisciplinary approaches. It might be termed an inter-paradigmatic period. But it is also a time of great intellectual excitement-of experimentation, exploration, critical ferment, and lively debate. 


\section{NOTES}

1. Universities in cities such as Barnaul, Chelyabinsk, Chita, Ekaterinburg, Ivanovo, Irkutsk, Izhevsk, Kaliningrad, Kazan,Krasnoyarsk, Krasnodar, Kursk, Moscow, Nizhni Novgorod, Novosibirsk, Omsk, Perm, Petrozavodsk, Rostov-on-Don, St. Petersburg, , Syktivkar, Tver, Tomsk, Tyumen, Ufa, Vladimir, Vladivostok, Volgograd, Vyatka, Yaroslavl.

INDEX

Keywords : Fulbright, canon, Russian Federation, Annual Conference of Soviet Literary Scholars, Moscow University, Spectacle, Nation, Popular Literature, Mythmaking, Intercultural Communication, Values 